\title{
Brazilian craft breweries and internationalization in the born global perspective
}

\author{
Fabricio Stocker \\ FGV-EBAPE - Brazilian School of Public and Business Administration, \\ Getulio Vargas Foundation, \\ Rio de Janeiro, Brazil \\ Gustavo Abib \\ Universidade Federal do Paraná - UFPR/PPGADM, Curitiba, Brazil \\ Ronaldo de Oliveira Santos Jhunior \\ Faculdade de Economia, Administração, Contabilidade e Atuária - FEA/USP, \\ Universidade de São Paulo, Sao Paulo, Brazil, and \\ Helio Arthur Reis Irigaray \\ FGV-EBAPE - Brazilian School of Public and Business Administration, \\ Getulio Vargas Foundation, \\ Rio de Janeiro, Brazil
}

\begin{abstract}
Purpose - This paper aims to analyze how the internationalization process of Brazilian microbreweries takes place, especially in factors of propensity to internationalization, competition and survival in the national and international market.

Design/methodology/approach - The authors adopted qualitative approach research, using a multiple case study strategy, analyzing seven Brazilian craft breweries. The authors developed this study through documentary research, semi-structured interviews and nonparticipant observation.

Findings - The research findings made it possible to characterize the internationalization process motivated by the background and international experience of entrepreneurs that adopted different strategies for expansion in the international market. The authors noticed that the networks developed in production partnerships, festivals and international missions represent an increase in the ease of internationalization and helps to reduce the risk perception.

Research limitations/implications - The contributions refer to the conjecture that the born global's evolution related to the high competitiveness of the market is influenced by the international background of the founders and by the influence of the international network, overcoming institutional and market challenges in emerging countries, assuming risks associated with rapid and early entry into the international arena.

Practical implications - The paper is potentially useful for managerial practice and policymakers by providing insights into the characteristics of entrepreneurs and companies considering their propensity to internationalize, presenting how entrepreneurs and managers can seek resources and develop their skills and capacities to manage such companies and processes of internationalization.
\end{abstract}

(C) Fabricio Stocker, Gustavo Abib, Ronaldo de Oliveira Santos Jhunior and Helio Arthur Reis Irigaray. Published in Revista de Gestão. Published by Emerald Publishing Limited. This article is published under the Creative Commons Attribution (CC BY 4.0) licence. Anyone may reproduce, distribute, translate and create derivative works of this article (for both commercial and non-commercial purposes), subject to full attribution to the original publication and authors. The full terms of this licence may be seen at http://creativecommons.org/licences/by/4.0/legalcode

This work was supported in part by grants from CAPES - Brazilian Federal Agency for Support and Evaluation of Superior Education within the Ministry of Education of Brazil, and CNPq - Brazilian National Council for Scientific and Technological Development within the Ministry of Science and Technology of Brazil.
Born global international

Received 22 January 2021 Revised 14 April 2021 Accepted 23 April 2021 
REGE 28,2
Originality/value - The research is presented as a complementary study to the limited number of studies examining born globals from emerging markets, also challenging the arguments of the dominant theory regarding gradual and nonlinear internationalization.

Keywords International strategy, Internationalization, Born global, Emerging markets

Paper type Research paper

\section{4}

\section{Introduction}

The globalization phenomena and the technological advances occurring in the last decades have been changing the functioning and the pace of expansion of companies around the world (Cavusgil, Knight \& Riesenberger, 2014). With the globalized market, the internationalization process happens more quickly, even for small and newly created companies (Efrat \& Shoham, 2012; Fan \& Phan, 2018; Stocker \& Abib, 2019).

The recent technological innovation and the presence of a growing number of entrepreneurs with international business experience have facilitated learning and increased the network of relationships between multinational companies and internationalized small and medium enterprises (Ghannad \& Andersson, 2012; Vaillant, Lafuente \& Bayon, 2018). By this point, micro and small enterprises with limited resources begin to compete and succeed in the international arena (Bjørgum, Moen \& Madsen, 2013; Jafari-Sadeghi, Nkongolo-Bakenda, Dana, Anderson \& Biancone, 2020).

In the context of the beer industry, the sector studied in this research, Brazil figures as the 3rd largest beer producer in the world, with the domestic market concentrated in only a few corporations, which together are responsible for more than $90 \%$ of all beer production. Despite being a highly competitive environment and dominated by large companies, in recent years, small enterprises have emerged as potential players in the market, mainly through international collaborations and global brand positioning, the so-called craft breweries.

Despite the ongoing debate about the born global companies, little is known about these types of companies (Sui \& Baum, 2014), and most of the studies on new international projects have been realized in developed countries - Knight \& Cavusgil (2004), Oviatt \& McDougall (2005) and Kubíćková, Tuzová \& Toulová (2016) - whose presence of born global companies are more evident. Hereupon, there is a lack of studies that are concerned about the peculiarities, advantages and disadvantages of companies from emerging markets (Bjørgum, Moen \& Madsen, 2013; Cuervo-Cazurra, 2016; Etemad \& Keen, 2018).

Considering the advances and latest research in the internationalization field, we can observe the expansion abroad of a new generation of companies originating in emerging countries (Etemad \& Keen, 2018). These new corporate structures, such as the case of born global, have challenged the international business theories, which argue mainly about expansion with gradual or by economic motivations, and thus, new research and more robust studies continue to be necessary for the advancement in the area (Ratten, Dana, Han \& Welpe, 2007; Cavusgil \& Knight, 2015; Reuber, Knight, Liesch \& Zhou, 2018).

Given the limited number of studies examining small born global, mainly from emerging countries, and also due to the lack of interlocution with the dominant theory of gradual internationalization, the objective of this paper is to analyze how the internationalization process of Brazilian microbreweries takes place, especially in factors of propensity to internationalization, competition and survival in the national and international market.

In addition to this first introductory section, the second section includes a review of internationalization and born-global theoretical background. In the third section, we present our methodological procedures, detailing the stages of data collection and analysis. The fourth and fifth sections are dedicated to the analysis and discussion of the achieved results. In the end, the final considerations of the work are presented, highlighting its contributions, limitations and propositions for future studies. 


\section{Theoretical background}

The internationalization of companies, influenced by the current global socioeconomic situation - caused by the development of emerging countries' economies and the participation of more countries in the international market - demands the expansion of the business and, with the internationalization process, benefits and advantages can be perceived by companies (Vaillant, Lafuente \& Bayon, 2018). Thus, the expected benefits of the internationalization strategy include increasing the degree of learning and skills development, expanding and diversifying the portfolio, cash flow and market area as well as reducing risk by participating in the global market (Zucchella \& Servais, 2012; Dal-sato, Alves, Bulé \& Amarante, 2015).

The adoption of internationalization strategies can be differentiated, with specific characteristics, however, they must be coherent with the organizational structure of the company and with the desired objectives in the international expansion (Reuber, Knight, Liesch \& Zhou, 2018; Jafari-Sadeghi, Nkongolo-Bakenda, Dana, Anderson \& Biancone, 2020). The main internationalization strategies for entry into foreign markets relate to exports, licensing, franchising - franchise, associations and strategic alliances, joint ventures and acquisition or installation of subsidiaries (Hitt, Ireland \& Hoskisson, 2012)

The internationalization of companies demanded by the need for business expansion and the adoption of competitive advantage strategies lead to consider the fact that little can be done on an individual basis, thus evidencing the need for interconnection with organizational networks (Krakawer, Jussani \& Vasconcellos, 2013; Jin, Ramkumar \& Chou, 2018). Such networks strategically and cooperatively respond to market uncertainties and position themselves in production and marketing in the international market (Zucchella \& Servais, 2012).

Organizational networks, according to Johanson \&Vahlne (2009), are a relevant element of understanding the internationalization process since with business relationships between companies, partners, buyers, suppliers and other stakeholders, there is an intensification of relationships and need for cooperation to work in an interconnected way (Ratten, Dana, Han \& Welpe, 2007; Jin, Ramkumar \& Chou, 2018).

The complementarity of the networks approach in the internationalization of companies is observed by the congruent benefits and advantages between the theoretical approaches, especially concerning the issues of risk reduction and uncertainties in the internationalization process through the influence and use of organizational networks (Zhao, Yang, Hughes \& Li, 2020).

However, according to Cavusgil, Knight, Riesenberger, Rammal \& Rose (2014), the perceived evolution in new international enterprises is clear evidence of the globalization phenomena and the persuasive impact of new technologies. This has generated a dissonance between the classical explanations about the internationalization process of traditional companies and of these new enterprises, opening space for novel discussions and theoretical perspectives about this phenomenon (Deng \& Sinkovics, 2017).

\subsection{The born global perspective review}

The rise of a new field of study in the international business literature, caused by the emergence of born-global companies in the early 1990s, created a challenge to the internationalization process's dominant theories (Bell, McNaughton, Young \& Crick, 2003). These new ventures have adopted a global vision since their conception or beginning of operations and have been dedicated to a rapid internationalization process (Rennie, 1993; Fan \& Phan, 2018).

The focus is on the age of companies when they become international not on their size (Dib, Da Rocha \& Da Silva, 2010). In contrast to organizations that gradually evolve from domestic
Born global international 
REGE 28,2 to multinational enterprises, these new ventures begin with a proactive international strategy.

Oviatt \& McDougall (2005) make a comparison of born-global companies with the internationalization theory by Johanson \& Vahlne (2009) and consider differences relating the assumptions of the Uppsala model, whose internationalization process is gradual. For born global, for instance, although resources may be limited by the size and time of existence and little or no experience in any market, yet these new ventures are committed to the international market, assuming the risks of their early operation (Cesinger, Danko \& Bouncken, 2012).

Although born global have been studied for more than a decade, theory and practice are still in the process of evolution (Gabrielsson \& Gabrielsson, 2011; Buckley \& Casson, 2021). There is no consensus and a clear definition about the concept of born global, which makes valid comparisons difficult (Dib, Da Rocha \& Da Silva, 2010; Cesinger, Danko \& Bouncken, 2012). For this reason, according to Gabrielsson, Kirpalani, Dimitratos, Solberg \& Zucchella, 2008, even after a long time of publication of the seminal work of Oviatt \& McDougall (1994), where born global was highlighted in the international entrepreneurship process, not enough is known about them.

Although there are different definitions of what the born-global company is, there is a certain agreement among international business researchers regarding their characteristics, whether concerning the short time they start their activities abroad, the involvement and commitment of their activities in the foreign market, the orientation to the international market or the factors that lead them to the accelerated process of internationalization (Bell, McNaughton, Young \& Crick, 2003; Knight, Madsen \& Servais, 2004; Deng \& Sinkovics, 2017).

This study adopts the definition of born global presented by Gabrielsson, Kirpalani, Dimitratos, Solberg \& Zucchella, 2008, who define a born global as a company with a global vision from the start, with potentially global products and services, and entrepreneurial capacity to accelerate the internationalization process. In an instrumental conception, Knight, Madsen \& Servais (2004) also delimit that the born-global firms internationalize on average within three years of founding and generates at least $25 \%$ of total sales from abroad.

In addition to the adopted definition, for operational issues of this study, it will be considered born global as a company intending to participate in the international market since its conception, moving rapidly to foreign markets, regardless of geographical coverage, billing percentage and the degree of internationalization - export, licensing, strategic alliances, acquisition, outsourcing of production or investment (Cavusgil, Knight, Riesenberger, Rammal \& Rose, 2004; Reuber, Knight, Liesch \& Zhou, 2018).

Contrasting to the traditional internationalization models of small and medium enterprises (SMEs), the born-global model is distinguished by its management having a global perspective. The growth rate of its international sales is faster, by the increase in organizational learning and the global market potential. For this reason, Gabrielsson, Kirpalani, Dimitratos, Solberg \& Zucchella, 2008 state that the founder and the global vision are key factors for understanding the born global; however, other variables need to be highlighted due to directly affect the born global progress, such as innovation, finance, corporate strategies, networking and organizational learning.

Madsen \& Servais (1997) proposed a model of search in born global, including different views of the phenomenon, as can be observed in Figure 1.

This research model was based on different investigations carried out in the field of new international enterprises, which separately analyzed individual, organizational and environmental issues. Including the characteristics of the entrepreneur/founder of the business, cognition issues, background training, work experience and cultural adaptation ease (e.g. Ghannad \& Andersson, 2012, Freixanet, Renart \& Rialp-Criado, 2018). The organizational characteristics of the enterprise include competencies, routines, internal process flow and corporate governance structure. And the characteristics of the external 


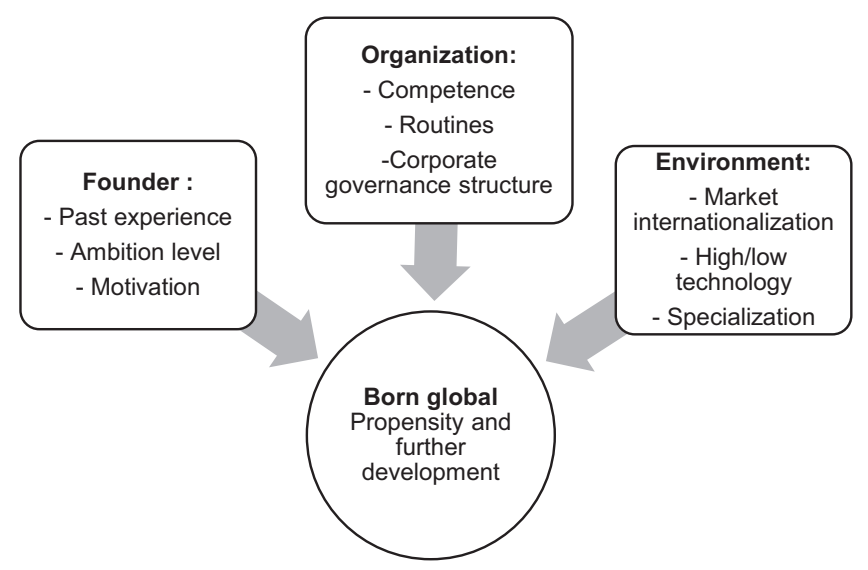

Born global international

Source(s): Madsen and Servais (1997)

Figure 1.

Research model in born

global

environment include the very dynamics of internationalization of the market and the technological advances influenced mainly by the phenomenon of globalization.

\subsection{Born global in international business - taking stock and looking ahead}

The research approach on born global makes three types of contributions: (1) show the emergence of the phenomenon in the international business field (Rennie, 1993; Oviatt \& McDougall, 2005; Servantie, Cabrol, Guieu \& Boissin, 2016; Zucchella, 2021), (2) the born global firm defies generalization of models of traditional firms internationalization processes (Knight, Madsen \& Servais, 2004) and (3) requires new theoretical structures to explain the phenomenon (Madsen \& Servais, 1997; Gabrielsson \& Gabrielsson, 2011; Buckley \& Casson, 2021).

Much of the research in born global has been conducted in developed countries, as Johanson \& Marttson (2015) analyzing Spanish Firms, Sui \& Baum (2014) analyzing Canadian firms and Trudgen \& Freeman (2014) analyzing Australian firms. They are additionally focusing on high-technology companies such as Ughetto (2016) with technologybased born global firms from Israel, and Harveston, Kedia \& Davis (2000) with i-business firms from Sweden and Germany.

In the context of research in emerging countries, there is a concentration of studies mainly in China (Tan \& Mathews, 2015); there is thus a space for further studies and advances in the area in enterprises of different emerging market countries and more traditional and less dynamic sectors. Just as studies are prevalent in specific cases and of multinationals in Brazil and other countries in Latin America, thus emerging a fertile field of research in SMEs that represent the majority of business in these countries (Krakawer, Jussani \& Vasconcellos, 2013; Suzin, Gonçalo \& Garrido (2014); Dal-sato, Alves, Bulé \& Amarante, 2015; CuervoCazura, 2016).

\section{The context of the study and the research methodology}

\subsection{Brazilian and the emerging market context}

This study is conducted and applied in the context of micro and small Brazilian companies, internationalized or the process of internationalization. It seeks to emphasize the emerging market context, evidencing relevant points that have an impact on the interpretation of the results, as well as on the contribution of the study. Proper contextualization of studies in 
REGE 28,2 international business, as emphasized by Teagarden, VonGlinow \& Mellahi (2018), can potentially improve the accuracy and relevance of the results, enabling replicability, generalization or definition of specificities for application in different cases.

The beverage industry was chosen, specifically the beer market, which is highly competitive in Brazil. The use of this specific context aims to ensure the homogeneity of companies in the institutional, social and economic field (García-Cabrera, García-Soto \& Durán-Herrera, 2016), thus facilitating the analysis of the effect of the perception of each individual on the risk and factors related to the process of internationalization.

Although craft breweries, some of which are called microbreweries, represent roughly $1 \%$ of the total volume of the beer sector in Brazil and around $2.5 \%$ of sales revenue in the country, they have presented more than $91 \%$ growth in the last three years. They are changing the Brazilian beer culture, with numerous festivals, events, specialty stores and international recognition through awards in different beer contests.

According to MAPA (2019), the Ministry of Agriculture, Livestock and Food Supply of the Federal Government, by the end of 2019, 944 craft microbreweries had been recorded in Brazil. Among these, some breweries, despite having operated in the market for less time, already have the intention or are in the process of internationalizing, through direct or indirect production, strategic partnerships and alliances for production and distribution, and the outsourcing and importing of products, among other internationalization strategies.

\subsection{Research method and case/data collection strategy}

To analyze the internationalization process of craft breweries, qualitative exploratory research was carried out, with the adoption of the multiple case study strategy (Eisenhardt, 1989).

The interviews were concentrated on the entrepreneurs/founders and managers of the organizations, which in most companies are also the brew masters responsible for the creative and productive process of the company. The interviews were conducted in the period from July to December 2016, and all speeches were recorded for subsequent transcription and content analysis. The nine interviewed entrepreneurs were nominated as interviewee 01,02 , until 09. The names of the selected companies were hidden in the research for privacy reasons. The average time of the interviews was $60 \mathrm{~min}$.

A relevant factor for the choice of breweries is the access to the founders of the organization, which, according to the research model in born global, is fundamental to understand the propensity and the process of development of the company's internationalization; this was one of the criteria for choosing the interviews. All entrepreneurs were part of the foundation of the company and today, they are responsible for the operation and management of the internationalization process.

Considering the born-global craft breweries as the object of research, the following selection criteria were adopted to rank the main craft breweries in Brazil: (1) year of foundation: companies with up to five years of existence; (2) international activity: companies that are already involved in some international activity (collaborative production, export, importation of production carried out abroad, among others) or that have their internationalization project declared since the beginning of the company's conception; (3) awards: as a criterion of choice, breweries with prominence and awards were selected in the main beer festivals and competitions in Brazil - Brazilian Beer Contest in Blumenau (SC), South BeerCup (Latin America), Mondial de La Bière ( International Beer Competition). Table 1 shows the selected cases and their respondents.

\subsection{Collecting and analyzing data}

This study was carried out through documentary analysis, semi-structured interviews and nonparticipant observation. At first, a documentary analysis was carried out in the 


\begin{tabular}{|c|c|c|c|c|}
\hline $\begin{array}{l}\text { Case / Interviewee } \\
\text { position }\end{array}$ & $\begin{array}{l}\text { Founded in and } \\
\text { internationalization } \\
\text { begins }\end{array}$ & International activity & Countries & $\begin{array}{l}\text { Born global } \\
\text { international }\end{array}$ \\
\hline $\begin{array}{l}\text { Case } 1 \\
\text { Interviewee } 1 \\
\text { (Entrepreneur and } \\
\text { CEO) } \\
\text { Interviewee } 2 \\
\text { (Commercial director) }\end{array}$ & $2009-4$ years & $\begin{array}{l}\text { Collaborative production, } \\
\text { imports, exports and } \\
\text { distribution }\end{array}$ & $\begin{array}{l}\text { United States, Canada, } \\
\text { France, Australia, } \\
\text { United Kingdom, Italy } \\
\text { and Belgium }\end{array}$ & \multirow[t]{2}{*}{169} \\
\hline $\begin{array}{l}\text { (Commercial director) } \\
\text { Case } 2 \\
\text { Interviewee } 3 \\
\text { (Entrepreneur, } \\
\text { Brewmaster, and CEO) } \\
\text { Interviewee } 4 \\
\text { (Commercial director) }\end{array}$ & $2010-2$ years & $\begin{array}{l}\text { Collaborative production, } \\
\text { strategic alliances and } \\
\text { exports }\end{array}$ & $\begin{array}{l}\text { United States, Scotland, } \\
\text { Canada and Denmark }\end{array}$ & \\
\hline $\begin{array}{l}\text { Case } 3 \\
\text { Interviewee } 5 \\
\text { (Entrepreneur, } \\
\text { brewmaster and CEO) }\end{array}$ & 2013- the same year & Collaborative production & $\begin{array}{l}\text { United States and } \\
\text { central America }\end{array}$ & \\
\hline $\begin{array}{l}\text { Case } 4 \\
\text { Interviewee } 6 \\
\text { (managing partner, } \\
\text { founder and } \\
\text { brewmaster) }\end{array}$ & 2013 - 1year & $\begin{array}{l}\text { Imports, collaborative } \\
\text { production, strategic } \\
\text { alliances and exports }\end{array}$ & $\begin{array}{l}\text { United States, } \\
\text { Denmark, Sweden, } \\
\text { Western Europe and } \\
\text { Scandinavia }\end{array}$ & \\
\hline $\begin{array}{l}\text { Case } 5 \\
\text { Interviewee } 7 \\
\text { (Entrepreneur, } \\
\text { brewmaster and CEO) }\end{array}$ & $2010-3$ years & $\begin{array}{l}\text { Collaborative productions } \\
\text { and strategic alliances }\end{array}$ & $\begin{array}{l}\text { United States and } \\
\text { Germany }\end{array}$ & \\
\hline $\begin{array}{l}\text { Case } 6 \\
\text { Interviewee } 8 \\
\text { (Entrepreneur, } \\
\text { brewmaster and CEO) }\end{array}$ & 2011- 4 years & Internationalization project & England & \\
\hline $\begin{array}{l}\text { Case } 7 \\
\text { Interviewee } 9 \\
\text { (Entrepreneur, } \\
\text { brewmaster and CEO) }\end{array}$ & \multirow[t]{2}{*}{$2009-5$ years } & \multirow[t]{2}{*}{ Internationalization project } & \multirow[t]{2}{*}{ South America } & $\begin{array}{r}\text { Table 1. } \\
\text { Identification and } \\
\text { presentation of the }\end{array}$ \\
\hline Source(s): Elaborated 1 & & & & selected cases \\
\hline
\end{tabular}

companies studied; this analysis was made on documents, websites, electronic media reports, and internal documents, according to the availability of access and also the reliability given to these documents, using different information as well. In this phase, a basis was sought for the elaboration of the questions related to the characterization of the companies and to assist in the subsidization of possible questions to be discussed during the interviews. Besides, we created a timeline with the companies' internationalization process, which also served as a guide during the interview phase.

As a second stage for data collection, interviews were conducted following a semistructured form, which was standardized according to aspects brought up from the literature review. Besides, this format also allows the emergence of new questions during the interviews. During the interviews and in the step of approaching the field, nonparticipant observation was carried out as a data collection strategy. According to Yin (2013), the observation aims to understand the facts and situations of the company and confront them with other sources of data, especially during the interview phase. A study protocol and a basic script for the semi-structured interviews with the study's guiding questions were 
REGE

28,2 followed during this data collection stage, as well as a free and informed consent term was also used for security issues and reliability of the study.

The interview script was structured in three blocks of questions, representing the dimensions to be explored, namely: (1) characteristics of the organization (organizational capacity, production, scope of international work); (2) characteristics of the entrepreneur (background, international professional experience) and (3) perceptions about the external context (competition, risks involved in internationalization, institutional factors and the macro-environment in which the company operates).

As a method to analyze the collected data, in this research, the content analysis was used with the support of Atlas.ti software. It allows systematic procedures and objectives to describe the content of the messages aiming to obtain indicators that allow the construction of knowledge related to the variables inferred from the messages (Bardin, 2006).

In structuring the collection and analysis of the data, a hermeneutic unit was created where the entire process of coding and analyzing the data was concentrated. For this, the interviews were recorded, and with the notes and field form, all data were transcribed and transferred to the Atlas.ti software. After that, based on the review of the literature and the research models in born global (Madsen \& Servais, 1997), the codes used to map the reports considered important for the analysis were defined.

\section{Discussion and analysis}

During the six months of data collection, dozens of participations and field observations were made. This stage of data collection in the field provided a closer relationship with the selected cases and a better context for the interview analysis. With the participation in events, it was possible to observe that most of the labels and marks launched by the companies were already directed to the international market, using expressions in English or German (languages of the major brewing markets of the world) or with local and regional nomenclature and ingredients, seeking the appreciation and differentiation of the Brazilian product, often well evaluated during the internationalization process of the company.

\subsection{The characteristics of the entrepreneur}

A decisive factor between the implementation of an expansion project for the international market and an expansion to the domestic market is conditioned to the skills and productive capacities and innovation in the organizational level of these companies influenced by the founder level of ambition.

This pattern among entrepreneurs is already evident in the literature, as highlighted in Freixanet, Renart \& Rialp-Criado, 2018 recent studies, on the influence of managers' global orientation on the process of internationalization of companies. An example of this can be observed in the excerpt from the interview:

The international design of the brewery was very well structured and planned, it was not by chance, it was many hours of study and work on that. (Interviewee 8).

Before the brewery, with the importer, there were connections with international producers and also with local commerce. On the one hand, the partnership with internationally renowned brewers and, on the other hand, access to points of sale, such as supermarket chains, for example. Between these two points, a free path to dare. (Interviewee 3).

A common characteristic of new international ventures born global is the presence and high engagement of the founder of the company, in this case of the breweries, the entrepreneurs before opening the business, already produced craft beers. Besides, eight of the nine 
interviewees had specific training for beer production with international certifications, having also a professional history in multinational companies and international background in education and business practice.

The characterization of born global, it was evident that the founders of the companies studied, most have some international experience, whether personal or previous work in multinational companies, and this factor is linked to the level of ambition and motivation to make the international company shortly after its foundation, a situation already evident in studies in born global as Gabrielsson, Kirpalani, Dimitratos, Solberg \& Zucchella, 2008, Ghannad \& Andersson (2012).

I had the experience of living abroad. I lived in England for a while and then also in Germany. I lived next to a PUB. And then I went back to Brazil, but I found it strange that I didn't have the different beers I had there, and then I started to search the internet myself, and I had the idea to do this here, set up the craft brewery (Interviewee 6).

One of the entrepreneurs had already lived in London for a long time, he already knew breweries, then through other trips that we made in Europe, we met others, we created a relationship with master brewers that we imported, and then more partnerships for production emerged. (Interviewee 3)

The importance given to international experience and founder networks is a reflection of the strategies adopted from the start of the internationalization process of these born-global breweries. This corroborates the findings of Ratten, Dana, Han \& Welpe, 2007, Krakawer, Jussani \& Vasconcellos (2013), Jin, Ramkumar \& Chou (2018) and Ribau, Moreira \& Raposo (2018), who argue that social networks play an important role in the development of born global enterprises, as well as in the choice of strategies for internationalization. This is also pointed out in studies on the preponderant factors in international entrepreneurship (JafariSadeghi, Nkongolo-Bakenda, Anderson \& Dana, 2019; Stocker \& Abib, 2019).

\subsection{The internationalization process and the organizational capacity}

According to Fan \& Phan (2018), the decision to internationalize the company is influenced by the size of the company's domestic market and also by its inaugural capacity of production. Likewise, Knight \& Liesch (2016) argue that in small and saturated domestic markets the propensity to internationalization is greater.

Concerning the process of internationalization of the breweries studied, the first steps followed by these companies are through participation in international fairs and festivals, where the first contacts and strengthening of the brand occur abroad, after which partnerships are held and collaborative productions take place, being able to use as much the factory unit of the Brazilian brewery as of the foreign brewery.

From that moment we have the export, which in some cases was carried out sporadically and, in others, it is already done continuously, then the production carried out totally abroad, representing a relationship and greater confidence in the international partner, import of that beer produced abroad, and finally the use of acquisition strategies and implementation of foreign subsidiaries.

It is also possible to observe that the internationalization process, that is, the choice of the strategies for entry in the international market, as shown in Figure 2, does not have a very big change regarding the level of commitment and investment of the company. In other words, for some sectors in which the born global is developed, as the case of technology-based companies, the entry modes on the international market are more aggressive, with high investments and strong commitment of company resources (Dib, Da Rocha \& Da Silva, 2010), But in the case of artisanal breweries, the adopted strategies follow a close pattern with the other SMEs that with time begin to operate abroad.

Born global international 
REGE 28,2

Figure 2.

The

Internationalization process of the studied breweries

\section{Table 2.}

The propensity to the internationalization of the cases studied
The characteristics of the internationalization process of the born-global companies studied can be highlighted as being companies with proactive strategy and with the intention of internationalization from the beginning, aiming of exploring knowledge and increasing competitive advantages, with a focus on high-end markets and strong involvement with relationship networks, in the input modes using more collaborative strategies (licensing, partnerships) and using self-financing for growth. Table 2 shows excerpts from interviews in which the entrepreneurs highlight the importance of each stage of the internationalization process carried out by the breweries.

During the analysis of the history and structure of the organizations studied, it was possible to observe that large parts of the companies, during the development of the business, were acquiring knowledge and improving their skills for international expansion. The productive capacity is a limiting factor highlighted by the companies, still smaller than the demand for products to supply the local and international market and also the lack of access

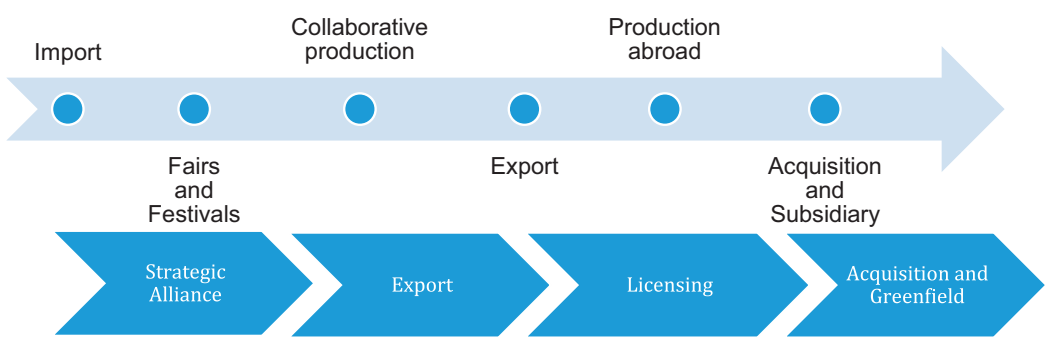

Source(s): Elaborated by the Authors (2021)

\begin{tabular}{|c|c|}
\hline Interviewee & Interview excerpt \\
\hline Interviewee 1 & $\begin{array}{l}\text { "The intention to have an internationally recognized product has existed since the beginning, } \\
\text { so much so that less than } 2 \text { years after the creation of the company, we were already a gold } \\
\text { medal at the Mondial de laBière in Belgium, and from that moment on, many collaborative } \\
\text { approaches and productions were taking place. And today, we both export and import our } \\
\text { beer produced abroad to Brazil" }\end{array}$ \\
\hline Interviewee 3 & $\begin{array}{l}\text { "We already thought of everything, which is why we have already created a characteristic } \\
\text { Brazilian name! and in a short time, the brewery has already partnered with big international } \\
\text { names." }\end{array}$ \\
\hline Interviewee 4 & $\begin{array}{l}\text { "Today, there is a very large mixture. So, this allows the product here to have global potential. } \\
\text { And this is a type of market that accepts innovation very well. So, we have always had this } \\
\text { vision and this intention, so much so that we have already done the documentation to qualify } \\
\text { as a player in the foreign market." }\end{array}$ \\
\hline Interviewee 8 & $\begin{array}{l}\text { "Regarding international activity, from the beginning, we had this vision and that is why we } \\
\text { launched innovative and daring products for the market [...] and the experience with the North } \\
\text { American market is being very positive and helped us to implement new work models and } \\
\text { management, paving the way for new destinations. The result of this is the participation and } \\
\text { export for the fourth time to the copenhagen BeerCelebration, in Denmark, which is a great } \\
\text { opportunity for breweries to take special projects out of the paper, highlighting creative ideas } \\
\text { and excellence in the production process. Also, it is a great opportunity to meet new breweries, } \\
\text { trends and strengthen relationships with contacts from all over the world." }\end{array}$ \\
\hline
\end{tabular}

Source(s): Research data 
to government and investment incentives, causing companies to have to plan and fund the growth with its own capital.

\subsection{The influence of the macro context and the environment}

In the analysis of the environment and internationalization of the market, a strategy widely used by breweries is collaborative production, where different companies share revenues and their production processes, unite resources and production skills and share the risks and profits of this business partnership. The breweries environment, although highly competitive considering its biggest market players, appears to be cooperative when it comes to SMEs, thus strengthening a network of stronger relationships and with more collaborations, be it between national or international breweries.

The entry mode decision and international strategy for each entrepreneur come to consider beyond these points, the complexity of the market to have its business expanded, a prominent concern also in the cases studied by Zucchella \& Servais (2012), when in the process of internationalization of SMEs.

The environment of craft beers in Brazil is still recent, but has been developing at great strides. In this environment of growing demand and receptive to innovations and differentiated products, they arise opportunities for the actions of internationalization. Table 3 shows some excerpts from interviews that refer to the international activities developed by the breweries and the environment of these companies.

Still, in the environment characterization, it was evidenced that innovation and creativity are decisive factors for the development of craft breweries. This also helps in the propensity to quickly internationalize Brazilian breweries that invest in innovative products with global potential.

Comparing the process of internationalization of born-global companies with other SMEs, it is evident that the studied companies have a proactive strategic motivation, committed management and an international vision since its foundation. In its expansion process, the companies studied developed strong relationships with networks and focused on leading markets, where the beer market already has a certain maturity and demands high-quality products, which is in line with the argument of other authors such as Gabrielsson, Kirpalani, Dimitratos, Solberg \& Zucchella, 2008, Knight \& Liesch (2016).

The findings of this research contradict what Parente, Cyrino, Spohr \& De Vasconcelos (2013) when concluding that the process of internationalization of companies from emerging markets, as in the Brazilian case, is quite unstructured and evolves as a reaction to the opportunities they face in international markets. In the companies investigated in this study,

\footnotetext{
Interviewee Interview excerpt

Interviewee 3 "We made several collaborative productions, outside Brazil, we already made several exports, practically all over Europe, and until last week, a friend of mine sent a photo of a pub in London and there was our product, he said: I believe, look what I found here!"

Interviewee 4 "We have done 3 international collaborations and this exchange of experiences is very legal, and of course this is very beneficial for the brand for the market projection both in terms of Brazil and abroad."

Interviewee 6 "Today, we work with supplies and top-quality ingredients, much of it is imported, so our beers do not lose anything for the outside beers, other than the issue of business know-how, and the courage to be innovative in the business."

Interviewee 8 "So, we had a vision of the international market, for some reasons, exporting is a good business because it adds value to the brand, the public here recognizes it as a potential brand, and you pulverize your business and decrease its dependence on the domestic market."
}

Source(s): Research data
Born global international 
REGE 28,2

we perceived that the internationalization process is planned and structured and comes as a result of an intentional process from the business conception, not only as an opportunity and unintended or programmed activity, as happens in other traditional ventures and also with the gradual internationalization of companies, as described by the behavioral approach of Johanson \& Valhne (2009).

\section{Concluding remarks}

This research aimed to analyze how the internationalization process of Brazilian Born Global companies takes place. For that, a qualitative study of multiple cases with craft breweries was carried out, due to the relevance and growth of this sector, even in a highly competitive environment as in the case of the Brazilian beverage industry.

According to this research, the decision to internationalize is based more on the intention of the entrepreneur to have his product at an international level than on the saturation of the domestic market, especially in the brewing business studied in Brazil, where the domestic market is large and with potential growth. However, the production capacity of breweries studied has been limited, which means that companies often have to choose between expanding and serving the local market or starting and continuing to expand and service international operations.

It is also possible to conclude that, as already mentioned by Jin, Ramkumar, \& Chou (2018), the use of networks, whether through formal or informal commercial relations, are developed in the new markets, with the partnerships of production, participation in festivals and international missions represents an increase in the ease of internationalization, and the use of these networks also functions as a reducing the perception of risk by the entrepreneurs of companies born global, as has been substantiated by Johanson \& Mattsson (2015), Grazzi \& Moschella (2018), Ribau, Moreira \& Raposo (2018), Cahen \& Borini (2020).

\subsection{Implications and contributions}

Our study makes several contributions to the literature. First, it refers to the fact that the emergence and internationalization of born global companies originating in developing countries, may be related to the lack of political and economic instability of the country, and in response to the weakness of the domestic market, the internationalization of the companies occur in a short time. Another contribution reflects the fact that the growing evolution of bornglobal companies, large domestic markets, may be related to high internal competitiveness and the need to exploit foreign markets, even though a niche potential domestic market.

Specifically for global born theory, the results discussed here contrasts with the arguments from the perspective of the born global whose internationalization behavior is nonlinear, but rather, it comes close to the arguments of the Uppsala model's gradual internationalization, but with an intense propensity and speed, in comparison with others small and medium-sized companies, thus facing greater risks due to early exposure to the international market.

This study also contributes to the literature in emerging markets, discussing the characteristics of entrepreneurship and small businesses within this context, present a more aggressive strategic positioning. This positioning plot an advantage more intensely on their contacts' networks, develop their organizational capacities and are willing to compete in developed markets, even culturally and geographically distant, which has been attracting interest from researchers in this area, and at the same time, it contrasts with the dominant assumptions of international business literature.

\subsection{Managerial implications}

The paper is also potentially useful for managerial practice. It provides additional insights on the characteristics of entrepreneurs and enterprises and the relationship with the propensity 
to internationalize. The entrepreneurs and managers of these businesses can seek resources and develop their skills and capabilities to better managing such ventures with rapid international insertion. As well as for public policymakers and local development actions, such as what already happens in some projects which empower and develop mentoring and business monitoring programs during its design and early years of operation.

There is also a potential interest in public policymakers and regional development actions, such as what already happens in some projects - such as Sebrae - Brazilian Service of Support to Micro and Small Enterprises, which empowers and develops mentoring and business monitoring programs during its design and early years of operation. Our results show practical elements that can be included in these training programs and that can be evaluated by public policies and financial or governmental incentives to support small enterprises and foster entrepreneurship in these regions.

\subsection{Limitations and research agenda}

We are aware of the limitations of this study and take this opportunity to suggest directions for extending our research. First, there is a divergence in the studies of born globals due to the application of its concept. Several authors make use of the born global expression, but there is no consensus regarding its characteristics and conceptual definition, which imposes limits on this research operationalization, as well as comparison with other studies. Second, it is the context and sector for conducting the research, the brewing industry of an emerging country, and thus its generalization needs to be marked out under these conditions.

For a research agenda is relevant to understand the internationalization of small enterprises originating in emerging countries in comparison with small enterprises of a developed economy country, evaluating risk factors, social and economic, institutional environment, the level and size of domestic markets, government influence on business strategies and how all these variables can facilitate or block the rapid process of internationalization of born global. Another study possibility refers to the construction of global networks of relationships in international enterprises and how these relations influence the degree of internationalization of born global and in the perception of risks in international activities.

\section{References}

Bardin, L. (2006). Analysis content. Oxford: Oxford University Press.

Bell, J., McNaughton, R., Young, S., \& Crick, D. (2003). Towards an integrative model of small firm internationalisation. Journal of International Entrepreneurship, 1(4), 339-362.

Bjørgum, O., Moen, O., \& Madsen, T.K. (2013). New ventures in an emerging industry: Access to and use of international resources. International Journal of Entrepreneurship and Small Business, 20(2), 233-253.

Buckley, P.J., \& Casson, M. (2021). Thirty years of International Business Review and international business research. International Business Review, 101795.

Cahen, F., \& Borini, F.M. (2020). International digital competence. Journal of International Management, 26(1), 1-17.

Cavusgil, S.T., \& Knight, G. (2015). The born global firm: An entrepreneurial and capabilities perspective on early and rapid internationalization. Journal of International Business Studies, 46(1), 3-16.

Cavusgil, S.T., Knight, G., Riesenberger, J.R., Rammal, H.G., \& Rose, E.L. (2014). International Business. Pearson Australia. 
REGE 28,2
Cesinger, B., Danko, A., \& Bouncken, R. (2012). Born Globals:(almost) 20 years of research and still not 'grown up'?. International Journal of Entrepreneurship and Small Business, 15(2), 171-190.

Cuervo-Cazurra, A. (2016). Multilatinas as sources of new research insights: The learning and escape drivers of international expansion. Journal of Business Research, 69(6), 1963-1972.

Dal-sato, F., Alves, J.N., Bulé, A.E., \& Amarante, C.C. (2015). O Processo de Internacionalização da Empresa de Software TOTVS sob a Ótica da Abordagem Comportamental. Revista de Gestão, 22(4), 493-508.

Deng, Z., \& Sinkovics, R.R. (2017). Rapid expansion of international new ventures across institutional distance. Journal of International Business Studies, 49(8), 1010-1032.

Dib, L.A., Da Rocha, A., \& Da Silva, J.F. (2010). The internationalization process of Brazilian software firms and the born global phenomenon: Examining firm, network, and entrepreneur variables. Journal of International Entrepreneurship, 8(3), 233-253.

Efrat, K., \& Shoham, A. (2012). Born global firms: The differences between their short-and long-term performance drivers. Journal of World Business, 47(4), 675-685.

Eisenhardt, K.M. (1989). Building theories from case study research. Academy of Management Review, 14(4), 532-550.

Etemad, H., \& Keen, C. (2018). Managing rapid change and rapid-growth in emerging industries. International Journal of Entrepreneurship and Small Business, 34(4), 480-499.

Fan, T., \& Phan, P. (2018). International new ventures: revisiting the influences behind the "bornGlobal' firm. International Entrepreneurship: The Pursuit of Opportunities across National Borders, 131-172.

Freixanet, J., Renart, G., \& Rialp-Criado, A. (2018). The impact of managers' global orientation on SME export and economic performance. Management International Review, 58(4), 571-604.

Gabrielsson, M., Kirpalani, V.M., Dimitratos, P., Solberg, C.A., \& Zucchella, A. (2008). Born globals: Propositions to help advance the theory. International Business Review, 17(4), 385-401.

Gabrielsson, M., \& Gabrielsson, P. (2011). Internet-based sales channel strategies of born global firms. International Business Review, 20(1), 88-99.

Ghannad, N., \& Andersson, S. (2012). The influence of the entrepreneur's background on the behaviour and development of born globals' internationalisation processes. International Journal of Entrepreneurship and Small Business, 15(2), 136-153.

Grazzi, M., \& Moschella, D. (2018). Small, young, and exporters: New evidence on the determinants of firm growth. Journal of Evolutionary Economics, 28(1), 125-152.

Harveston, P.D., Kedia, B.L., \& Davis, P.S. (2000). Internationalization of born global and gradual globalizing firms: The impact of the manager. Journal of Competitiveness Studies, 8(1), 92.

Hitt, M.A., Ireland, R.D., \& Hoskisson, R.E. (2012). Strategic Management Cases: Competitiveness and Globalization. Boston: Cengage Learning.

Jafari-Sadeghi, V., Nkongolo-Bakenda, J.M., Anderson, R.B., \& Dana, L.P. (2019). An institution-based view of international entrepreneurship: A comparison of context-based and universal determinants in developing and economically advanced countries. International Business Review, 28(6), 101588.

Jafari-Sadeghi, V., Nkongolo-Bakenda, J.M., Dana, L.P., Anderson, R.B., \& Biancone, P.P. (2020). Home country institutional context and entrepreneurial internationalization: The significance of human capital attributes. Journal of International Entrepreneurship, 18, 165-195.

Jin, B., Ramkumar, B., \& Chou, W.H.C. (2018). Identifying sources and roles of networks in international expansion among small businesses in a less-technology-intensive industry. International Journal of Entrepreneurship and Small Business, 34(4), 421-444.

Johanson, J., \& Mattsson, L.G. (2015). Internationalisation in industrial systems-a network approach. Knowledge, Networks and Power, 111-132, Palgrave Macmillan, London. 
Johanson, J., \& Vahlne, J.E. (2009). The Uppsala internationalization process model revisited: From liability of foreignness to liability of outsidership. Journal of International Business Studies, 40(9), 1411-1431.

Knight, G.A., \& Cavusgil, S.T. (2004). Innovation, organizational capabilities, and the born-global firm. Journal of International Business Studies, 35(2), 124-141.

Knight, G.A., \& Liesch, P.W. (2016). Internationalization: From incremental to born global. Journal of World Business, 51(1), 93-102.

Knight, G., Madsen, K. T., \& Servais, P. (2004). An inquiry into born-global firms in Europe and the USA. International Marketing Review, 21(6), 645-665.

Krakawer, P.V.C., Jussani, A.C., \& Vasconcellos, E.P.G. (2013). A utilização de alianças estratégicas na internacionalização de pequenas e médias empresas: Estudo de caso em uma empresa brasileira de tecnologia da informação. Revista de Gestão, 20(3), 299-311.

Kubíčková, L., Tuzová, M., \& Toulová, M. (2016). The internationalisation of small and medium-sized enterprises as a path to competitiveness. Competitiveness, Social Inclusion and Sustainability in a Diverse European Union, Springer, Cham, 99-120.

Madsen, T.K., \& Servais, P. (1997). The internationalization of born globals: An evolutionary process?. International Business Review, 6(6), 561-583.

Oviatt, B.M., \& McDougall, P.P. (2005). Toward a theory of international new ventures. Journal of International Business Studies, 36(1), 29-41.

Parente, R.C., Cyrino, Á.B., Spohr, N., \& De Vasconcelos, F.C. (2013). Lessons learned from Brazilian multinationals' internationalization strategies. Business Horizons, 56(4), 453-463.

Ratten, V., Dana, L.P., Han, M., \& Welpe, I. (2007). Internationalisation of SMEs: European comparative studies. International Journal of Entrepreneurship and Small Business, 4(3), 361-379.

Rennie, M.W. (1993). Born global. The McKinsey Quarterly, (4), 45-53.

Reuber, A.R., Knight, G.A., Liesch, P.W., \& Zhou, L. (2018). International entrepreneurship: The pursuit of entrepreneurial opportunities across national borders. Journal of International Business Studies, 49(4), 395-406.

Ribau, C.P., Moreira, A.C., \& Raposo, M. (2018). Categorising the internationalisation of SMEs with social network analysis. International Journal of Entrepreneurship and Small Business, 35(1), 57-80.

Servantie, V., Cabrol, M., Guieu, G., \& Boissin, J.P. (2016). Is international entrepreneurship a field? A bibliometric analysis of the literature (1989-2015). Journal of International Entrepreneurship, 14(2), 168-212.

Stocker, F., \& Abib, G. (2019). Risk management in born globals: The case of Brazilian craft breweries. Brazilian Business Review, 16(4), 334-349.

Sui, S., \& Baum, M. (2014). Internationalization strategy, firm resources and the survival of SMEs in the export market. Journal of International Business Studies, 45(7), 821-841.

Suzin, J.B., Gonçalo, C.R., \& Garrido, I.L. (2014). A mobilização de recursos estratégicos como perspectiva de análise de um processo de internacionalização: A expansão da azaleia para o mercado sul-americano. Revista de Gestão, 21(1), 83-102.

Tan, H., \& Mathews, J.A. (2015). Accelerated internationalization and resource leverage strategizing: The case of Chinese wind turbine manufacturers. Journal of World Business, 50(3), 417-427.

Teagarden, M.B., Von Glinow, M.A., \& Mellahi, K. (2018). Contextualizing international business research: Enhancing rigor and relevance. Journal of World Business, 53(3), 303-306.

Trudgen, R., \& Freeman, S. (2014). Measuring the performance of born-global firms throughout their development process: The roles of initial market selection and internationalisation speed. Management International Review, 54(4), 551-579.

Ughetto, E. (2016). Growth of born globals: The role of the entrepreneur's personal factors and venture capital. International Entrepreneurship and Management Journal, 12(3), 839-857. 
REGE

28,2

178
Vaillant, Y., Lafuente, E., \& Bayon, M.C. (2018). Early internationalization patterns and export market persistence: A pseudo-panel data analysis. Small Business Economics, 1-18.

Yin, R.K. (2013). Validity and generalization in future case study evaluations. Evaluation, 19(3), 321-332.

Zhao, W., Yang, T., Hughes, K.D., \& Li, Y. (2020). Entrepreneurial alertness and business model innovation: The role of entrepreneurial learning and risk perception. International Entrepreneurship and Management Journal, 1-26.

Zucchella, A. (2021). International entrepreneurship and the internationalization phenomenon: Taking stock, looking ahead. International Business Review, 101800.

Zucchella, A., \& Servais, P. (2012). The internationalisation process of small-and medium-sized firms and the liability of complexity. International Journal of Entrepreneurship and Small Business, 15(2), 191-212.

\section{Corresponding author}

Ronaldo de Oliveira Santos Jhunior can be contacted at: ronaldojhr@usp.br

Associate Editor: Aidin Salamzadeh

For instructions on how to order reprints of this article, please visit our website: 